\title{
The role of government and accounting in the development of academic research commercialisation: The New Zealand experience
}

\author{
Anil K Narayan \\ Faculty of Business and Law, AUT University, Auckland, New Zealand, e-mail: \\ anarayan@aut.ac.nz; phone: 9219999 ext 5121, fax: 9219990
}

\section{Acknowledgements}

The author wishes to acknowledge the feedback received on the earlier version of the paper presented at the sixth Accounting History International Conference, Wellington, New Zealand, 18-20 August 2010. The invaluable advice of two anonymous reviewers is also gratefully acknowledged. 


\title{
The role of government and accounting in the development of academic research commercialisation: The New Zealand experience
}

\begin{abstract}
Over the past three decades, many nations accelerated their efforts to develop academic research commercialisation to help drive their innovation and productivity goals. Despite failure to achieve the desired results, surprisingly very few studies have examined how research commercialisation initiatives are designed at the government level. This study reviews the historical role of the government and the interplay between significant shifts in research direction, funding and accounting that contributed to the development of academic research commercialisation in New Zealand. The paper concludes that funding pressures combined with the government's lack of early recognition and formal endorsement of research commercialisation as a vital activity has contributed to previous low levels of academic research commercialisation. The important lessons to be learnt from the New Zealand case are that academic research commercialisation requires a coherent long-term national strategy that is responsive, promises results and has funding incentives.
\end{abstract}

Keywords: Academic research commercialisation, accounting, government, new public management, innovation. 


\section{Introduction}

Universities are often viewed as rich reservoirs of unexploited commercialisable intellectual property (Mowery, Nelson, Sampat, and Ziedonis, 2001; Rosenberg and Nelson, 1994) that put them at the centre stage of creation and diffusion of new knowledge considered essential in driving the innovation and economic development plans of many nations (OECD, 2008; Rasmussen, Moen, and Gulbrandsen, 2006). In the United States, Congress passed the Bayh-Dole Act in 1980 to ensure the USA's competitiveness in the world economy and universities were given a central role in the commercialisation of research to help drive the nation's innovation and productivity goals. Since then, a number of government initiatives have been taken in many countries, especially in the UK (HM Treasury, 2004), across Europe (Commission of the European Communities [COM], 2003), and Canada (AUCC, 2001), to recognise and enhance universities’ engagement in commercialisation of academic research.

Despite the broad acceptance by governments around the world of the importance of research commercialisation (Nordfors, Sandred, and Wessner, 2003) and its contribution to economic performance (Dahlstrand, 2008; Lindelof and Lofsten, 2003; Lofsten and Lindelof, 2002), many nations lagged behind in terms of academic research commercialisation (Goldfarb and Henrekson, 2003). There is accumulating evidence that previous government policies failed to achieve the desired results in the form of economic growth and knowledge transfer to industry (Dahlstrand, 2008; Goldfarb and Henrekson, 2003). Surprisingly, very few studies examined the role of the government and how initiatives are designed at the government level to achieve the intended research commercialisation objectives (Rasmussen, 2008).

This paper provides a New Zealand case study that contributes to a more comprehensive understanding of the role of the government and the use of accounting in the 
development of academic research commercialisation. It is intended that this historical research will help explain why previous government policies failed to achieve the desired research commercialisation results and what lessons can be learnt from the New Zealand experience. The acquiring of resources and financial incentives are necessary components of research commercialisation development. However, the interplay between significant shifts in research policy direction, funding, and associated links with accounting and accountability mechanisms to facilitate research commercialisation is not well understood. Accounting is best understood in the contexts in which it operates, and rather than being perceived as a mere technical practice, accounting is increasingly perceived as a social practice (Carnegie and Napier, 1996; Miller, 1994; Potter, 2005). Hence, it is important to examine the use of accounting through different political agendas (Hopwood, 2005) to “demonstrate an appreciation” for its “pervasive and enabling characteristics” (Potter, 2005, p. 265).

The New Zealand case is particularly interesting for several reasons. The government is a significant player in the nation's innovation system and sees commercialisation of research as an important way to create benefits for New Zealand. It put innovation at the centre of its economic policy and established various science and innovation-related mechanisms aimed at strengthening the innovative efforts of the nation. The government finances about half the country's investment in research, science and technology, owns research infrastructure, notably, Crown Research Institutes (CRIs) and is committed to supporting commercialisation of research activities (MoRST, 2006). It relies on the tertiary education system to produce knowledge, skills and innovation to transform the economy and give effect to its vision on academic research commercialisation (TEAC, 2001a). The government provides the strategic direction and formulates research priorities for tertiary institutions. In return for the public investment in research for tertiary institutions, the government has been seeking enhanced commercialisation and rapid diffusion of new ideas 
and technologies into all sectors of the economy (MoRST, 2006). Despite the efforts of the government, the performance of the nation's innovation system failed to keep pace with other developed countries. New Zealand continues to lag behind in terms of the gross domestic product per capita (OECD, 2007) and ranks towards the bottom end of the OECD productivity league (OECD, 2009). Although tertiary institutions produce significant amounts of research, there is a strikingly low rate of transfer to business (Ministry of Education, 2003).

Information for this study was obtained from a review of literature and archival sources of data including the government reform reports and research policy documents. Accompanying legislative framework and research funding mechanisms were also examined. The focus of this paper is on research in general, since basic research funding for tertiary institutions is performance based with an emphasis on research quality, as opposed to research disciplines. In order to get an in-depth understanding of the government policy initiatives, a total of ten face-to-face semi-structured interviews were conducted with wellinformed persons such as government policy advisors, senior academic researchers, university policy makers, research commercialisation managers and chief executives. The case description was written based on collected material and sources verified by interviewees. The study utilises neo-liberalism and new public management (NPM) ideologies as appropriate theoretical perspectives for analysis. It is within this theoretical framework that major public sector transformations took place across many nations including New Zealand.

The paper continues with an outline of neo-liberalism and NPM theoretical perspectives that informs the study. Next, it provides a historical overview of the government reform agenda on research commercialisation. It then presents the reforms of the tertiary sector and the government's vision on academic research commercialisation. Within these contexts, the interplay between significant shifts in research policy direction and funding and 
the pervasive and enabling characteristics of accounting in influencing the development of research commercialisation is also examined. The paper concludes with an assessment of the role of the government and provides important lessons to be learnt from the New Zealand experience.

\section{Neo-liberalism and NPM perspectives}

Neo-liberalism became globally accepted as a set of political and economic discourses necessary to restructure and reconstitute essential public sector services as part of the competitive realities of the market (Davies, Gottsche, and Bansel, 2006; Harvey, 2005; Peters, 2006). The underlying policy framework of neo-liberalism is marked by a shift from Keynesian welfarism towards a political economy theory favouring market mechanisms as a means of ensuring societal well-being (Larner, 2000). The superiority of the market forces with its association with free trade, international competition, economic efficiency and consumer choice is seen as a better way of transforming government activity (Butterworth and Butterworth, 1998; McKenna, 2000). Neo-liberalism embraces the philosophy of globalisation, deregulation, privatisation and minimal involvement of government in the direct provision of public services (Larner, 2000). According to Clarke (1997), neo-liberalism disintegrated the conceptions of the public as a collective identity by attempting to substitute individualised and economised identities as taxpayers and consumers. Thus, neo-liberal strategies encouraged individual entrepreneurship that privileges private property accumulation co-ordinated by markets (Harvey, 2005). This means that competition and consumer demand supplanted the norms of public service with each individual becoming responsible for enhancing their own well being by exercising autonomous choices. Through the lens of governmentality, neo-liberalism encouraged the framing of public expenditure in terms of what the government could afford (Clarke, 2004). It promoted technologies such as 
budget disciplines, accounting, and audit as useful mechanisms of public sector governance (Olssen and Peters, 2005).

In the transformation of public sector organisations, neo-liberalism has been expressed through NPM practices (Servage, 2009). NPM can be best understood as an ideological configuration of neo-liberal strategies that emphasise individual rights, market freedom and competition in achieving the overall economic well being of the society (Olssen, 2002). By advocating the use of markets and market driven changes in the organisation and management of the public sector, NPM defined new forms of administrative orthodoxy about how public services are run and regulated (Deem and Brehony, 2005). It introduces the entrepreneurial spirit to innovate public sector organisations and there is greater reliance on private sector ideas and business practices regarded as far superior to the public sector (Hood, 1995). Some of the main characteristics of NPM include less bureaucracy, devolved management, public-private partnerships and the development of quasi-markets for service (Olssen, 2002). These are aimed at fostering competition, both internal and external to the organisation, in the interests of driving maximum efficiency and effectiveness in the overall provision of public service (Deem, 2001). NPM places greater emphasis on accountability as a clear assurance that the organisation is operating as efficiently and effectively as possible (Hood, 1995; Olssen, 2002). It imposes clear requirements on accountability through the inclusion of the widespread use of performance indicators and performance management systems, as well as enhanced forms of monitoring and reporting systems to hold the organisation and its workers accountable for maximum efficiency (Deem, 2001). The underlying dominant themes include comprehensive corporate planning, shift from inputs to output and outcome measures, the introduction of performance based remuneration systems and letting managers manage through the devolution of management control (Aucoin, 1990; Boston, Martin, Pallot, and Walsh, 1991; Deem, 2001; Hood, 1995). 
As a consequence of NPM's call for greater efficiency, effectiveness and accountability, the domain of accounting expanded and assumed far greater prominence beyond levels previously recognised (Hopwood, 1992; Miller, 1994; Power, 1994). It created financial forms of visibility that has implications not only for the functioning of the organisation, but also for the society as a whole (Carnegie and Napier, 1996; Miller, 1994; Potter, 2005). Hence, accounting is increasingly perceived as a social and institutional practice rather than merely a technical practice (Potter, 2005). Within the social and institutional paradigm, accounting is a device for intervening in the functioning of organisations and societies to help understand activities, processes and the manner in which social reality is constructed (Miller, 1994). The NPM ideologies based on efficiency, effectiveness, accountability, transparency and autonomy have become institutionalised and fairly well established in transforming public sector organisations in global contexts. It became increasingly popular in countries such as New Zealand, Britain, Australia, Canada, and the United States through its emphasis on a strong social demand for better public management (Boston, 1991; Boston, Martin, Pallot, and Walsh, 1996; Deem and Brehony, 2005; Ferlie, Pettigrew, Ashburner, and Fitzgerald, 1996). The New Zealand experiment based on neo-liberalism has been described as the most ambitious attempt in reinventing government using NPM ideologies (Gray, 1998). How this influenced the development of academic research commercialisation is further analysed in the paper.

\section{Historical overview of the government reforms - the broader context}

In New Zealand, the origins of the research commercialisation strategy can be traced back to the more general reforms of the Department of Scientific and Industrial Research (DSIR). The DSIR, established in 1926, was the central authority administered by an independent governing council that co-ordinated, funded and supported the research efforts of 
the government (Galbreath, 1998). In 1935, the DSIR began to undertake more research itself resulting in a programme of expansion and centralisation of science and industrial research and by 1949 it added eight further research divisions and trebled its staff numbers (Galbreath, 1998). The DSIR received central funding allocations from the government and relied heavily on traditional budgeting as the key accounting mechanism to allocate funding to other public research bodies. Accounting, a technical practice privileged with characteristics of neutrality, objectivity, calculability and usefulness for decision-making (Gomes, 2008; Miller and O'Leary, 1993), enabled both the DSIR and the government to administer and govern in a disciplined manner according to budgeted facts. The budget also served as an important planning and control mechanism and budget allocations helped determine the research agendas and priorities for the DSIR and other government agencies.

Greater reliance on the budget as a central control mechanism became evident in 1950 when it helped the government rein in the DSIR's spending. But then growth continued with the expansion of the DSIR's role into research departments undertaking research in competition with other government departments. According to Galbreath (1998), by 1963, the DSIR's council lost its usefulness as a central co-ordinating body for research and was replaced by a more independent National Research Advisory Council that administered the funding allocations and set separate budgets of the DSIR and other departments, each with its own priorities. In 1970, the National Research Advisory Council adopted a more coherent policy for national science with an overall science budget. Research policy and planning guided by budget formulations allowed for the overall coordination of the government's research agenda.

The science budget plan, depicted as a successful accounting mechanism, evolved and helped construct and facilitate the national scientific effort. In this manner, accounting became "intimately implicated in the construction and facilitation of the context" (Hopwood, 
Burchell, and Clubb, 1994, p. 228) leading to the growth of the DSIR by 5 percent a year and its expansion to a total of 2,097 staff and 20 research divisions by 1976 (Galbreath, 1998). Following the oil shock of 1973, the government was forced to curb expenditure and from 1976, the DSIR like all other government departments had controls on expenditure, including a requirement to charge for services where possible. This in itself became an interesting accounting challenge for the scientists as the characteristics of science and business were very different in terms of motivation, purpose and operating values (Edmeades, 2004). The charging for services directed attention to ways in which accounting exerted an influence and, in turn, became influenced by economic factors (Miller, 1994) thus intensifying the debate on research commercialisation.

\section{Commercialisation of the DSIR}

The transformation or reinvention of the New Zealand public sector began in 1984 with the election of the fourth Labour Government that initiated sweeping changes (Boston, 1991) and promised to liberalise the economy by using competitive market forces (Easton, 1997). With the government intent on relying on the logic of market forces and its economic liberalisation policy to transform the nation's research activity, the DSIR came under considerable pressure to become more commercial. In 1984, the government imposed expenditure controls and introduced 'user pays' policy in the DSIR, not only as a cost recovery measure, but also to encourage a customer-contractor approach (Galbreath, 1998). The government policy took a firm view that it should not be funding or subsidising research of direct commercial value. It also took the hard line approach of cutting funding of the DSIR and other research agencies by the amount it considered users should be paying. From 19841988, government funding to the DSIR was progressively reduced by a total of 25 per cent which led to the DSIR more actively seeking customers willing to contract for its research services (Galbreath, 1998). 
The commercial model based on the user pays policy presented its own accounting challenges in terms of adopting appropriate costing and pricing models. The role of accounting expanded to include an understanding of full cost recovery models and pricing policies. It required identification of the direct and indirect costs of research. The criteria for categorising overhead costs associated with research pricing had to be determined and then certain indirect costs attributed to the total cost of research in a more systematic manner. The introduction of the user pays policy marked the advent of the NPM reforms allowing the logic of market forces to determine where research and development would yield the highest commercial returns using the accounting criteria of costing and pricing. The NPM reforms also set the research commercialisation agenda that was subject to considerable political debate and led to the formation of various working parties to advise the government.

\section{The research commercialisation debate}

The Treasury supported research commercialisation using an economic argument that insisted on letting the markets and the user pays principle decide where research and development were likely to yield the maximum returns (Treasury, 1987). The DSIR scientists on the other hand argued for government research funding for the good of the nation and its economic development priorities (Galbreath, 1998). However, the Treasury economists insisted that better economic performance would result from a more competitive economic environment by separating the funders and providers, and introducing contestability in funding allocations with an emphasis on purchasing outputs rather than funding inputs. To the scientists, the economic arguments of the Treasury did not measure up and in an effort to convince the Treasury officials of the value of research; the scientists relied on the accounting measures of internal rate of return on a number of research projects to determine its value to the economy (Galbreath, 1998). Throughout the 1980s, this was the accepted accounting 
measure and reliance on this technical dimension of accounting was more an effort to seek greater legitimacy for funding use.

While the debate continued over funding issues, gradually the commercial market model became accepted by most scientists. As recorded by Devine (2003, p. 70), "the science community had itself failed to grasp the significance of the reforms” and some supported it for “opportunistic reasons rather than conviction”. By this time the 'market failure' argument also emerged as a rationale for the government to deliver funding for basic research in the long-term interest of research development or where research had social value but was not marketable. In 1988, the idea that research should be funded for the 'public good' as well as for strategic and future economic benefits was recommended by the Science and Technology Advisory Committee, the last of a succession of official working parties to recommend on the restructuring of science. This working party also recommended the restructuring of science along market lines as advocated by the Treasury economists. The government accepted these recommendations, and in 1989, a new Ministry of Research, Science and Technology was established to provide policy advice to the government. In 1991, the Foundation for Research, Science and Technology was established as an independent funding agency to allocate government funding for research from the Public Good Science Fund.

\section{Establishment of the Crown Research Institutes (CRIs)}

In 1992, the DSIR and other government science providers were restructured into ten CRIs to operate as commercial entities established under the Crown Institutes Act 1992. The Crown Institutes Act 1992 also abolished the DSIR and other science providers. The underlying benefits from this restructuring were identified as the provision of a clearer framework for management of all risks, the devolution of operational management decisionmaking, wider access to capital and enhanced management accountability (COMU, 2010). The primary intention was to encourage efficiency through competition and clear objectives 
and robust accountabilities with greater transparency and focus (Devine, 2003; Edmeades, 2004). The CRIs are subject to the Crown Entities Act 2004, the CRI Act 1992 and the Companies Act 1993. Each CRI is a registered company with independent board of directors appointed by the government. They manage their own resources and there is an expectation that the commercial criteria would provide a fair assessment of their managerial performance. The primary objective of setting the CRIs as separate companies is to ensure the transformation of much of the commercial research into profit-making activities and to create a positive shareholder value. This perhaps explains why the tenth CRI responsible for social research was subsequently disbanded in August 1995 due to its failure to establish commercial viability (COMU, 2010).

The transformation of the CRIs as commercial entities was greatly assisted by the introduction of 'business accounting' methods. This was facilitated by the CRI Act which required the CRIs to generate, on the basis of generally accepted accounting principles, an adequate rate of return on shareholders' funds (equity) which reflects the cost of that equity. According to the Crown Ownership Monitoring Unit, the CRIs have become more market focused, exhibit a much stronger and more pervasive strategic focus, and have greater performance expectations than the departments from which they were formed (COMU, 2010). They have become much stronger organisations since the time of their establishment. In the year ended June 2009, the CRIs employed in excess of 4,200 staff, and in terms of financial performance, reported a collective operating surplus of \$25.2 million. Their total operating income increased by $\$ 28.8$ million to $\$ 677.9$ million and total assets were valued at $\$ 701.9$ million at 30 June 2009, up from \$668.7 million at 30 June 2008 (Statistics New Zealand, 2009). It is interesting to note that such accounting measures are typical performance measurements of a commercially focused business organisation and the role of accounting expanded to meet the financial accounting requirements of profitability and 
shareholder value creation. Accounting not only emerged as a powerful technical practice, it was used as an intervening device to help transform the CRIs and address the institutional pressures of reforms (Miller, 1994).

The transformation of the government research organisations based on neo-liberalism and NPM ideologies set the commercialisation agenda. It brought market discipline into the research efforts of the government. However, the government funding cuts and accounting performance measures emphasised revenue and profits that made CRIs chase funds as their primary purpose at the expense of a much broader research commercialisation mission (Devine, 2003). While this behaviour was a logical response to the governance and funding incentives utilised by the government, the strategic and policy directions of the government did little to encourage the CRIs to develop research commercialisation and optimise contribution to the wider community (Winsley, 2003). The reforms of the DSIR and changes in wider research policy set the context for reforms in the tertiary education sector.

\section{The tertiary education sector reforms}

\section{Period 1980-1989: Setting the reform agenda}

The restructuring of the government research organisations based on neo-liberalism set the context for the reform of the tertiary education sector. Prior to the early 1980s, education was considered a 'public good' that was freely available to all citizens. Education, including all research was block grant funded by the government as an important investment in building the wealth generating capacity of the nation, as well as making a worthy contribution towards the greater good of society. The Hawke Report on post-compulsory education and training in New Zealand, published in July 1988, became a significant starting point of debate in the commercialisation process of tertiary education (Hawke, 1988). The report recommended that universities become more commercial with the ability to generate private funds and set their own fees. It also recommended the separation of teaching and 
research, and the use of contractual forms of accountability through charters and performance appraisal systems. Most of the Hawke Report recommendations were incorporated as the government's intended policies in the Learning for Life document (Ministry of Education, 1989a) with detailed recommendations on the implementation of these policies contained in the Learning for Life Two document (Ministry of Education, 1989b). These two documents emphasised neo-liberal market policies and maintained a similar commercial approach using free market forces to drive the tertiary education sector. The Learning for Life reforms resulted in some degree of corporatisation whereby tertiary institutions operated like private businesses utilising private-sector management practices (Olssen, 2002). However, while the period 1984 - 1989 was that of experimentation with the government withdrawing from many areas of economic production in the general public sector, education continued to be understood as a social good rather than an economic investment (Larner \& Le Heron, 2005).

\section{First university commercialisation office established}

A significant development in university research commercialisation was in 1988 . The University of Auckland established UniServices, the first university commercialisation company in New Zealand to handle all commercial research contract and consultancy work coming out of the university. Hood (2001) argued that public research funding levels for the tertiary sector was far too little in comparison to international standards, so in a partial response to this problem, UniServices was formed to generate funding for the university to help build its research capacity. This important development signalled the introduction of research commercialisation in the New Zealand tertiary education sector. Within three years of the formation of UniServices, all eight New Zealand universities established varying forms of research units and companies to undertake contract research and facilitate the development of research commercialisation opportunities. 
UniServices was set up as a limited liability subsidiary company with an independent board equally split between business and academic members. The commercial nature of its operations led to the decoupling of accounting from the university system to avoid bureaucratic compliance procedures of NPM and facilitate the adoption of business accounting and financial management practices to ensure that the commercial company was run as a profitable business. In effect, decoupling enabled accounting to operate in a different institutional context, that is, the commercial environment. Success in terms of commercialisation reported in the 2009 annual report of the University of Auckland was that the annual revenue grew by 17.4 percent to $\$ 114$ million for 2009 and it provided employment for 750 staff and researchers, and sponsored research for an additional 550 university researchers. There were 200 active patent families and 83 new invention disclosures in 2009. In 2008, the New Zealand Vice Chancellors Committee reported that universities were at the forefront of commercialising research results and the sector had a turnover of \$350 million a year. In the four years from 2003-2006, their combined activities had a total income of $\$ 1.2$ billion (New Zealand Vice Chancellors Committee, 2008). However, most of the income was generated from consultancy contracts and licence fees, and commercialisation of academic research in terms of new product development and technology transfer to business remains low (Ministry of Education, 2006a). This is because commercialisation is often long-term and requires substantial financial investment with no guarantee of outcomes and financial returns. In the absence of government policy and funding to support the development of commercialisation projects, many universities have no desire to risk their involvement and investment. In addition, with revenue targets widely recognised as a critical measure of commercialisation performance, it seems logical for universities to chase consultancy and research contracts that provide a guaranteed income. 


\section{Period 1990-1999: The influence of neo-liberalism and NPM}

In addition to the institutional and funding pressures that led to the establishment of university commercialisation structures, the influence of neo-liberalism set the policy agenda for exposing tertiary institutions to commercialisation using market forces. Under neoliberalism, education was reconstituted as an essential service or product to be traded in the marketplace (Davies et al., 2006; Peters, 1999). Neo-liberal strategies based on market principles of economic efficiency and effectiveness, accountability, transparency, autonomy and contestability largely influenced the development of education policy decisions. It also marked the implementation of NPM reforms with an emphasis on enhanced financial accountability and reporting requirements.

In 1990, the Learning for Life Two document was implemented. The 1990 Education Amendment Act provided the legislative framework for tertiary institutions to operate as autonomous and economically efficient 'businesses' with the introduction of bulk grants for teaching and research. Each tertiary institution was granted institutional autonomy with their own governing council that operated on a contractual model of accountability through charters, mission statements and performance objectives. To give effect to these new accountability and performance reporting requirements, major public sector accounting changes were implemented within the legislative framework of the Public Finance Act 1989. The tertiary institutions' financial statements were remodelled in terms of statements of objectives and statements of service performance, and annual reports became the key accountability document used to report to the government and other stakeholders on performance. Changes to the funding system were made with a mix of student fees and government loans as well as a separation of teaching and research with some innovation and science related research funding becoming more contestable. This was to ensure that the 
requirements for advanced high quality research portfolios with a strong strategic focus were met.

The tertiary institutions were encouraged to become more commercial with the freedom to generate private sources of revenue and set their own fees to supplement simultaneous reduction in bulk grants (Easton, 1997; Olssen, 2002). Commercialisation was facilitated by the implementation of significant accounting changes that included course costing and pricing mechanisms, programme budgeting and enhanced financial reporting systems. The role of accounting was expanded to include an understanding of full cost recovery models and pricing policies, identification of direct and indirect costs and establishment of the accounting criteria for categorising overhead costs associated with research and pricing of research projects. The nature of all costs required proper identification and recording in the accounts, and certain indirect costs attributed to the total cost of research and individual research projects required allocation to ensure pricing was done in a systematic manner.

The implementation of the calculative practices of accounting helped transform the tertiary institutions (Miller, 1994). Greater reliance on accounting and pricing methods facilitated the substantial increase in research funding generated from various private sources. The university generated research funds, including the student fee component, more than doubled from \$46.8 million in 1992/1993 to \$115.7 million in 1997/1998 (Johnson, 2000). The administrative reforms of the research sector, with the establishment of the Ministry of Research, Science and Technology and the Foundation for Research, Science and Technology, propelled fiscal conservatism on the part of the government to change the set of incentives that faced research funders and providers in order to bring about greater accountability, efficiency and private participation (Johnson, 2000). The 1990s saw a greater flow of both the public and private research funds into the universities with the total research 
funds from all sources increasing from \$232.4 million in 1992/1993 to \$403.5 million in 1997/1998. Of this total, the private sector research funding increased from $\$ 9.2$ million in 1992/1993 to \$18.8 million in 1997/1998, and the government funding for research increased from \$31.9 million in 1992/1993 to \$99.2 million in 1997/1998 (Johnson, 2000).

By the early 1990s, increasing student numbers brought increasing funding pressure that prompted the National Government to establish the Todd Committee to advise on the options for public and private funding. The Todd Report, published in 1994, reaffirmed the commercial logic and the neo-liberal strategy adopted by the government to manage public tertiary institutions (Easton, 1997). Throughout the 1990s, a series of reports continued to emphasise market driven approaches to improving the efficiency and accountability of the tertiary sector. This clearly reflected the overall trend of the government's major macro policies and the socio-economic reform agenda in which economic rationalism and market liberalisation remained the key features. The shift towards market driven entrepreneurship was the common trend in tertiary education in most OECD countries (Etzkowitz, Webster, Gebhardt, and Terra, 2000; Marginson and Considine, 2000; OECD, 2003; Vincent-Lancrin, 2006). Neo-liberalism redefined the very purpose of education and research leading to ‘academic capitalism’ (Slaughter and Leslie, 1997). Universities driven by a commercial and entrepreneurial spirit became commonly known as the ‘Enterprise University’ (Considine and Marginson, 2001). According to Codd (2005, p. 194), “successive New Zealand governments embraced neo-liberalism as allegedly the only solution to worsening economic conditions”. This optimism seems misplaced as neo-liberal strategies and policy directions of the government encouraged profit-seeking behaviours that failed to recognise research commercialisation as part of a system of innovation that delivered value from research in terms of social and economic development in the national interest. Neo-liberalism introduced commercialisation to the New Zealand tertiary sector (Larner and Le Heron, 2005), but the 
NPM initiatives of the government to bring market discipline to the research environment through funding cuts and accounting performance measures, only encouraged individual tertiary institution's to maximise their own revenue streams and profit at the expense of the development of a broader commercialisation mission.

During the 1990s, the "government did not have a strong focus on innovation as part of its economic policy approach”, and this lack of initiatives discouraged the tertiary institutions' engagement in academic research commercialisation (OECD, 2007, p. 156). At the beginning of the late 1990s, the perceived failings of the neo-liberal strategy started to emerge, and the new Labour-Alliance coalition government elected in November 1999 set out to change the direction of tertiary education. It appointed the Tertiary Education Advisory Commission to set a vision for tertiary education to pave the way for New Zealand to become a "world-leading knowledge society" (TEAC, 2000, p. 32).

\section{Period 2000-2009: An emphasis on innovation and nation building}

In 2000, the government recognised the growing importance of innovation to the nation's economic growth and put innovation at the centre of its economic policy. It appointed the Science and Innovation Advisory Council to comprehensively assess and advise on the New Zealand innovation system. Since 2000, the government also set the focus of the tertiary education system to produce knowledge, skills and innovation to transform the economy, promote social and cultural development, and contribute effectively to the development of a knowledge nation (TEAC, 2001a). In 2001, the Tertiary Advisory Commission released two reports that suggested that the neo-liberal policies were incompatible with the need to develop a knowledge society and that the tertiary policy must be aligned with important national strategic goals of innovation, and economic and social development (TEAC, 2001a, 2001b). Following various reviews and reports on innovation, 
the government in February 2002 set out its Growth and Innovation Framework with a major focus on returning New Zealand's per capita income to the top half of the OECD rankings (New Zealand Government, 2002). The government established the Growth and Innovation Advisory Board in May 2002 to provide it with high level independent strategic advice on growth and innovation issues. Among other issues, the advice the government received from this board was to recognise the importance of tertiary education research and commercialisation as key drivers of modern economies and thriving societies (New Zealand Government, 2002). This led to the establishment of the Tertiary Education Commission in 2003 to help provide strategic direction and formulate research priorities for the tertiary organisations.

\section{Tertiary Education Commission}

To give effect to the government's vision on research and innovation, the Tertiary Education Commission released the first Tertiary Education Strategy 2002-2007 that contained a key strategy (strategy six) to strengthen research, knowledge creation and uptake for the New Zealand knowledge society (Ministry of Education, 2003). Specific objectives relating to this strategy were to encourage and reward excellent research performance (objective 29); have a more focused tertiary research investment through world-class clusters and networks of specialisation (objective 32); ensure greater alignment of tertiary education research with national goals (objective 33); and improve knowledge uptake through stronger links with those that apply new knowledge or commercialisation of knowledge products (objective 34). Within this strategic framework, the Statement of Tertiary Education Priorities were formulated and released by the Minister of Education to give effect to these strategies. The views expressed by one government policy advisor during an interview were that "the government sees tertiary education as a powerful driver of economic performance. The 
government is very active in trying to create a framework and an environment which enables a transfer of knowledge to occur more readily” (Holmes.C, personal communication, 11 December, 2007).

Since 2002, a significant round of reforms began with the enactment of the Tertiary Education (Reform) Bill and the launch of the 2002-2007 Tertiary Education Strategy. The reforms were aimed at "shifting the attitudes, culture and focus" of the tertiary education sector to greater collaboration and rationalisation; more responsiveness to the needs of the communities; and ensuring that there is greater alignment with the nation's economic and social development goals (Ministry of Education, 2006b, p. 29). The government recognised that it needed to build university-industry-government collaboration that was important for research commercialisation. It established centres for research excellence to facilitate this partnership more commonly referred to as the 'triple-helix' of research commercialisation (Etzkowitz and Leydesdorff, 1997; 2000). The government also recognised the tertiary education sector as a major player in the nation's innovation system. It established the Performance-Based Research Fund (PBRF) Working Group to set the major strategic direction for research in tertiary education.

\section{Performance-Based Research Fund (PBRF)}

The PBRF Working Group recommendations revolutionised the tertiary research funding system by placing greater emphasis on research quality as a means of funding research in tertiary organisations (Ministry of Education, 2002). In the PBRF funding formula, 60 percent of research funding is based on research quality, 25 percent is based on research degree completions, and 15 per cent is based on external research income. The funding allocation for universities through the PBRF commenced in 2004 with \$16.3 million rising to \$201.1 million when it was fully implemented in 2007 (Ministry of Education, 
2010). During the phase-in period until 2007, the bulk of the research funding continued on the basis of student enrolments. Between 2002 and 2008, the total university research income rose by 102 percent from $\$ 297$ million to $\$ 600.6$ million. The total research contracts income rose by 90.3 percent from \$194.2 million in 2002 to \$369.5 million in 2008 (Ministry of Education, 2010). The PBRF Working Group reported that it expected that the PBRF will make a major contribution to the development of the nation (Ministry of Education, 2002). According to interviewees, PBRF drives the research culture of the tertiary institutions mainly because reward systems and funding incentives are tied to PBRF activities. The lack of commercialisation incentives is causing a culture clash among academic researchers and undermining the research commercialisation development.

\section{Other government initiatives and concerns}

In March 2006, the government agreed on an Economic Transformation Agenda to build on the directions set by the Growth and Innovation Framework for lifting New Zealand's innovation and economic performance and improving the income per capita. The government continued to develop its tertiary education strategy together with a number of science and innovation strategies. The government's goals for tertiary education as part of the Economic Transformation Agenda were to create and apply knowledge to drive innovation, improve the transfer and application of knowledge, supply research and knowledge to create commercial opportunities for New Zealand firms, connect effectively with businesses to realise these opportunities, and build the global awareness and lift productivity and innovation (Ministry of Education, 2006a).

According to a recent OECD report on tertiary education, investment in research and development is an important indicator of the effort government is putting into achieving scientific and technological progress (OECD, 2008). This report highlights that in GDP 
terms, tertiary education research and development expenditure increased steadily from $0.36 \%$ to $0.40 \%$ across the OECD nations between the period 2000 and 2005, but in New Zealand's case, it declined. The New Zealand government financed research and development expenditure is also much lower than the OECD average (MoRST, 2006). There are wider concerns that previous government policy settings failed to encourage innovative businesses, and historically low investments in both public and private research over many decades resulted in the lack of knowledge intensive industry in New Zealand (Gluckman, 2009). These shortcomings justify renewed calls for the government to fulfil its leadership role in the nation's research and innovation system.

The government has a major role to provide the policy frameworks for economic growth and innovation. Since 2000, it established various science and innovation related frameworks and advisory boards aimed at strengthening the innovative efforts of the nation. The government sees commercialisation from public research as an important way to create benefits for New Zealand and issued guidelines on intellectual property ownership, licensing and use. Three key ministries, the Ministry for Research, Science and Technology, the Ministry for Economic Development and the Ministry of Education, have pivotal roles in setting the research policy direction and funding administration. A number of other government policy agencies have important roles, such as the Ministry of Health which is involved in formulating health research policy and the Tertiary Education Commission has a strategic role in the development of tertiary education policy.

The government funding for research in the tertiary education sector is provided by the Tertiary Education Commission using the PBRF criteria. The Royal Society of New Zealand provides basic research funding to the tertiary sector primarily through the Marsden Fund, the Health Research Council provides funding for medical research, and the Foundation for Research, Science and Technology provides funding for strategic research. These 
independent authorities are funded by the Ministry of Research, Science and Technology. From 2002-2003, the government established seven Centres of Research Excellence to enable the development of a critical mass of inter-institutional and world-class research networks to help improve knowledge uptake and commercialisation of research. Each Centre of Research Excellence is hosted by a university and comprises a number of partner research organisations. Innovation related funding provided by the Tertiary Education Commission is aimed at improving the links between tertiary institutions, industry and business to help develop research capability and knowledge transfer, and encourage private sector investment. The government also established the New Zealand Venture Investment Fund Ltd in 2002 to address a shortage of venture capital to help facilitate commercialisation of innovation, and the Pre Seed Accelerator Fund was established in 2003 to help transform research results from publicly funded research into viable commercialisation prospects.

Although the government's role has been recognised through the establishment of various support programmes and funding mechanisms, there is to some extent, a lack of clarity between the roles of the government ministries and between those of their funding agencies (OECD, 2007). The Tertiary Education Strategy 2008-2012 highlights concerns that although tertiary institutions produce significant amounts of research, there is a low rate of transfer to business (Ministry of Education, 2006a). The OECD 2005 Annual Review of New Zealand report also highlights the strikingly low rate of collaboration and ideas flowing from universities and research institutions to businesses (OECD, 2005). It seems that misdirected government research agendas and funding policies combined with a lack of a coherent longterm national strategy discouraged the development of academic research commercialisation. The government, therefore, needs to urgently address these concerns to enhance research commercialisation opportunities from tertiary institutions. 


\section{Emphasis on accounting and accountability}

In the period 2000-2009, major changes to the government policy and research funding mainly through the implementation of the PBRF placed greater emphasis on accountability for research performance. The access to research funding became more competitive than in the past, and increasing proportions of available funds provided by government agencies were targeted for specific research purposes. As research and development remain significant spending categories in government budgets, the tertiary institutions are subject to greater public scrutiny due to concerns of public accountability. The allocation of public research funding has become increasingly characterised by research priority areas and outcomes, competitive bidding, and performance-based funding. The role of accounting with a strong technical dimension expanded to incorporate NPM measures of research performance, and reporting of results became highly institutionalised in terms of the PBRF criteria of income generation. The research commercialisation agenda of tertiary institutions place high priority on funding, budgeting, costing and pricing issues. Institutional accounting systems and procedures are designed to facilitate accounting for research income and expenditure at individual school and project level, as well as allow for research budgeting, cost management and contract pricing.

The tertiary organisations, as autonomous institutions, have the freedom to pursue self determined institutional objectives, but at the same time as public funded institutions, they are under increasing public pressure to utilise the outcomes of their research for the benefit of society. According to the OECD, the tension between the pursuit of self-determined institutional objectives and the broader research commercialisation objectives of the nation needs to be recognised and reconciled with an increasing focus on accountability and performance (OECD, 2008). The growing accountability demands emerging from the social and institutional contexts coerced the tertiary institutions into utilising positive reporting 
strategies to enhance their research reputation and public image. The strategic documents and annual reports of tertiary institutions largely imitate and represent the social and economic priorities of the nation to provide legitimacy and help obtain government funding. Hence, modern accounting comprising the social and economic agenda, institutionalised performance measures, and positive reporting narratives, is increasingly relied upon to create visibility and convey symbolic meanings (Miller, 1994). It helps transform and shape tertiary organisational activities and social interactions beyond its technical dimension (Hopwood, 1990).

\section{Summary}

This historical study examined over three decades of initiatives utilised by the New Zealand government to encourage the development of academic research commercialisation. The study explains how accounting was implicated within the context of academic research commercialisation development. The period up until the early 1990s was marked by the institutional transformation of the DSIR, New Zealand's largest state research organisation, to a new 'commercial model' based on the user pays policy. The government policy took a view that it should not be funding or subsidising research of direct commercial value. Accounting largely depicted by budget formulation was used successfully for research policy and planning, allocating research funds, and maintaining an overall coherence of the national research priorities. The role of accounting expanded to include costing and pricing models with the introduction of the user pays policy for research. The technical characteristics of accountability in terms of neutrality, objectivity, calculability, and usefulness for decisionmaking made it widely acceptable. In the tertiary education sector, the Hawke Report was the significant starting point in the debate in the commercialisation process. In 1988, funding pressures led to the establishment of the first university commercial company to pursue the 
commercialisation agenda, but the government was not proactive in leading any developments in the commercialisation of academic research.

The period 1990-1999 saw the implementation of the neo-liberal policies of the government in the tertiary education sector. This was a period of intense competition as tertiary institutions had the freedom to generate private sources of revenue. Significant accounting changes such as course costing and pricing models, programme budgeting and enhanced financial reporting systems were implemented within tertiary institutions. The technical role of accounting expanded to include an understanding of overhead allocation and full cost recovery models in pricing of research projects. Major public sector accounting changes were implemented resulting in the financial statements remodelled in terms of statements of objectives and statements of service performance. The annual reports became the key accountability document for reporting to the government and other stakeholders on research performance. Clearly, accounting was used as an intervening device to exert influence through greater reliance on its technical characteristics to assist the tertiary organisations’ functioning. It also helped permeate the ways in which research priorities, funding concerns, and new possibilities for action were expressed (Hopwood, 1990). During this period, the shift towards market driven entrepreneurship was a common trend, and tertiary institutions were strategically positioning themselves, restructuring, and establishing new organisational forms to take full advantage of the commercial opportunities presented by the market. Although teaching and research was separated with research funding becoming more contestable, the government initiatives failed to encourage the development of commercialisation of academic research. It was not until the end of 1999 that the full impact of the failings of government's neo-liberal strategy was realised.

In 2000, the government put innovation at the centre of its economic policy and recognised tertiary education as making an important contribution to the innovation and 
development plans of the nation. The Tertiary Education Strategy 2002-2007 document clearly laid out the government’s intent on academic research and recognised commercialisation as an important function. The government established Centres of Research Excellence to encourage greater collaboration with industry and implemented PBRF to reward research excellence in tertiary institutions. However, the PBRF failed to recognise and fund commercialisation of academic research making it a marginal activity in most tertiary institutions. Since 2000, the growing accountability demands expanded the role of accounting in tertiary institutions to incorporate measures of research performance and reporting of results. The social and institutional environment pressures influenced accounting to utilise positive reporting strategies to represent and imitate the government's research priorities. The annual report constructed as a positive narrative of research performance has become a key accounting mechanism to create visibility, help provide legitimacy and secure government funding. In this manner, accounting is increasingly relied upon as a social practice with symbolic meanings to help construct social reality (Carnegie and Napier, 1996; Miller, 1994; Potter, 2005). However, implicating accounting to push the government's political agenda has not influenced research commercialisation development in tertiary institutions.

\section{Conclusion}

The academic research commercialisation development has been marked by a history of misdirected government research agendas and funding policies resulting in a lack of a coherent national strategy on innovation and commercialisation. Previous government policies have been deficient in encouraging academic research commercialisation, and it was not until 2002 that government formally endorsed commercialisation as a vital activity and put it on its national policy agenda. It seems that after the NPM reforms of the 1990's, the incoming Labour government directed funds away from the market place and the needs of the 
New Zealand industry and enterprises which largely contributed to the nation's poor OECD rankings. The government's message to researchers was to do more with the same or less funding with the prevailing view that putting strategies and policies in place was generally sufficient to encourage research commercialisation. Even under the current PBRF policy initiatives, it is not mandatory for tertiary institutions to engage in commercialisation of academic research. It seems that the government has been too complacent about its policy initiatives which contributed to previous low levels of academic research commercialisation.

There are a number of important lessons to be learnt from the New Zealand experience. First, commercialisation calls for a long-term national strategy that is coherent, responsive and promises results. Second, academic research needs to be seen in terms of economic contributions and value-adding activities leading to commercial outcomes. Third, to ensure that research projects work towards an avenue of commercialisation, government policy needs to tie funding to the commercialisation potential of research activities. Fourth, commercialisation projects are long-term, uncertain and complex, and present considerable risks. The government initiatives need to recognise the entire value chain, beginning from the basic research to discovery and exploitation. Fifth, specific research grants need to be established and conditioned on tertiary organisations demonstrating that they are able to advance their research and innovation into the commercial market. Finally, recognising the pervasive and enabling characteristics of accounting will help facilitate research commercialisation development. 


\section{References}

AUCC. (2001), Commercialization of University Research, Ottawa: Association of Universities and Colleges of Canada, http://www.aucc.ca/_pdf/english/reports/2002/innovation/commercial_e.PDF (accessed 15 June 2008).

Aucoin, P. (1990), “Administrative Reform in Public Management: Paradigms, Principles, Paradoxes and Pendulums”, Governance, Vol. 3, pp.115-137.

Boston, J. (1991), "Reorganizing the Machinery of Government: Objectives and Outcomes”, in Boston, J., Martin, J., Pallot, J and Walsh, P (Eds.), Reshaping the State: New Zealand's Bureaucratic Revolution, Auckland: Oxford University Press, pp. 233-267.

Boston, J., Martin, J., Pallot, J. and Walsh, P. (1991), Reshaping the State - New Zealand's Bureaucratic Revolution, Auckland: Oxford University Press.

Boston, J., Martin, J., Pallot, J. and Walsh, P. (1996), Public Management: The New Zealand Model, Auckland: Oxford University Press.

Butterworth, G., and Butterworth, S. (1998), Reforming Education: The New Zealand Experience 1984-1996, Palmerston North: Dunmore Press Limited.

Carnegie, G. D. and Napier, C. J. (1996), “Critical and Interpretive Histories: Insights into Accounting's Present and Future Through its Past”, Accounting, Auditing and Accountability, Vol. 9, No.3, pp. 7-39.

Clarke, J. (1997), “Capturing the customer? Consumerism and social welfare”, Self, Agency and Society, Vol. 1:1, pp. 55-73.

Clarke, J. (2004), “Dissolving the public realm?: The logics and limits of neo-liberalism”, Journal of Social Policy, Vol. 33(01), pp. 27-48.

Codd, J. (2005), "Teachers as 'managed professionals' in the global education industry: the New Zealand experience”, Educational Review, Vol. 57, No. 2, pp. 193-206.

Commission of the European Communities [COM]. (2003), The Role of Universities in the Europe of Knowledge, COM 2003/58, http://europa.eu/scadplus/leg/en/cha/c11067.htm (accessed 18 May 2007).

COMU. (2010), Crown Research Institutes, http://www.comu.govt.nz/crown-researchinstitutes.html (accessed18 May 2010).

Considine, M. and Marginson, S. (2001), Enterprise University, Cambridge: Cambridge University Press.

Dahlstrand, A. L. (2008), University Knowledge Transfer and the Role of Academic Spin-offs, Paris: OECD.

Davies, B., Gottsche, M. and Bansel, P. (2006), “The Rise and Fall of the Neo-liberal University”, European Journal of Education, Vol. 41, No. 2, pp. 305-319.

Deem, R. (2001), “Globalisation, New Managerialism, Academic Capitalism and Entrepreneurialism in Universities: is the local dimension still important?”, Comparative Education, Vol.37, No.1, pp. 7-20.

Deem, R., and Brehony, K. J. (2005), "Management as Ideology: The Case of 'New Managerialism' in Higher Education”, Oxford Review of Education, Vol. 31, No. 2, pp. 217-235.

Devine, S. (2003), “A Systems Look at the Science Reforms”, New Zealand Science Review, Vol. 60(2-3), pp. 70-74.

Easton, B. (1997), The Commercialisation of New Zealand, Auckland: Auckland University Press.

Edmeades, D. C. (2004), “Is the Commercial Model Appropriate for Science?”, New Zealand Science Review, Vol. 61(3-4), pp. 85-92. 
Etzkowitz, H. and Leydesdorff, L. (1997), "Introduction to Special Issue on Science Policy Dimensions of the Triple Helix of University-Industry-Government Relations”, Science and Public Policy, Vol. 24, pp. 2-5.

Etzkowitz, H. and Leydesdorff, L. (2000), “The Dynamics of Innovation: From National Systems and "Mode 2" to a Triple Helix of University-Industry-Government Relations", Research Policy, Vol. 29(2), pp. 109-123.

Etzkowitz, H., Webster, A., Gebhardt, C. and Terra, B. R. C. (2000), “The Future of the University and the University of the Future: Evolution of Ivory Tower to Entrepreneurial Paradigm”, Research Policy, Vol. 29(2), pp. 313-330.

Ferlie, E., Pettigrew, A., Ashburner, L. and Fitzgerald, L. (1996), The New Public Management in Action, Oxford: Oxford University Press.

Galbreath, R. (1998), DRIS: Making Science Work for New Zealand: Themes from the History of the Department of Scientific and Industrial Research, 1926-1992, Wellington: Victoria University Press.

Gluckman, P. D. (2009), Improving Translation of Publicly Funded Research for Economic Benefit: Summary of the Workshop on 14 September 2009, Office of the Prime Minister's Science Advisory Committee, http://www.pmcsa.org.nz. (accessed 18 May 2010)

Goldfarb, B. and Henrekson, M. (2003), "Bottom-up versus Top-down Policies Towards the Commercialization of University intellectual Property”, Research Policy, Vol. 32, pp. 639-658.

Gomes, D. (2008), “The Interplay of Conceptions of Accounting and Schools of Thought in Accounting History”, Accounting History, Vol. 13, No. 4, November, pp. 479-509.

Gray, J. (1998), False Dawn: The Delusions of Global Capital, London: Granta Publications. Harvey, D. (2005), A Brief History of Neoliberalism, Oxford: Oxford University Press.

Hawke, G. R. (1988), Report of the Working Group on Post Compulsory Education and Training, Wellington: Ministry of Education.

HM Treasury. (2004), Science and Innovation Investment Framework 2004-2014, London: HM Treasury, Department of Trade and Industry and Department for Education and Skills.

Hood, C. (1995), “The 'New Public Management' in the 1980s: Variations on a Theme”, Accounting, Organisations and Society, Vol. 6, pp. 193-211.

Hood, J. (2001), “The Research-Led University: Reflections from New Zealand”, Menzies Oration on Higher Education, http://menziesfoundation.org.au/orations/Hood20011011.pdf (accessed 20 November 2010).

Hopwood, A. (1990), “Accounting and Organisation Change”, Accounting, Auditing \& Accountability, Vol. 3, No.1, pp. 7-17.

Hopwood, A. (1992), “Accounting Calculation and the Shifting Sphere of the Economic”, European Accounting Review, Vol.1, No.1, pp. 125-143.

Hopwood, A. (2005), “After 30 Years”, Accounting, Organisations and Society, Vol. 30, No.7-8, pp. 585-586.

Hopwood, A., Burchell, S. and Clubb, C. (1994), "Value-Added Accounting and National Economic Policy”, in Hopwood, A. and Miller, P. (Eds.), Accounting as Social and Institutional Practice, Cambridge: University Press, pp. 211-236.

Johnson, R. (2000), "Crowding Out and Resulting Trends in Research Fund Allocation in New Zealand, 1991-2000”, New Zealand Economic Papers, 34.1., http://find.galegroup.com.ezproxy.aut.ac.nz/gtx/infomark.do?\&contentSet=IAC- 
Documents\&type=retrieve\&tabID=T002\&prodId=EAIM\&docId=A79338339\&sourc $\mathrm{e}=$ gale\&srcprod=EAIM\&userGroupName=aut\&version=1.0 (accessed 15 June 2010).

Larner, W. (2000), “Neo-liberalism: Policy, Ideology, Governmentality”, Studies in Political Economy, Vol. 63, Autumn, pp. 5-25.

Larner, W. and Le Heron, R. (2005), "Neo-liberalizing Spaces and Subjectivities:

Reinventing New Zealand Universities”, Organization, Vol.12 (6), pp. 843-862.

Lindelof, P. and Lofsten, H. (2003), "Science Park Location and New Technology-Based Firms in Sweden - Implications for Strategy and Performance”, Small Business Economics, Vol. 20(3), pp. 245-258.

Lofsten, H. and Lindelof, P. (2002), "Science Parks and the Growth of New TechnologyBased Firms - Academic-Industry Links, Innovation and Markets”, Research Policy, Vol. 31(6), pp. 859-876.

Marginson, S. and Considine, M. (2000), The Enterprise University: Power, Governance and $R e$-invention in Australia, Cambridge: Cambridge University Press.

McKenna, S. (2000), “Commercialisation, Corporatisation and Privatisation - The Transformation of Government Enterprises as a Feature of Globalisation: A Case Study of Scientific Research”, Management Research News, Vol. 23(2-4), pp. 92-93.

Miller, P. (1994), “Accounting as a Social and Institutional Practice: An Introduction”, in Hopwood, A. and Miller, P. (Eds.), Accounting as Social and Institutional Practice, Cambridge: University Press, pp. 1-39.

Miller, P.and O'Leary, T. (1993), “Accounting Expertise and the Politics of the Product: Economic Citizenship and Modes of Corporate Governance”, Accounting, Organisations and Society, Vol. 18, No.2-3, pp. 187-206.

Ministry of Education. (1989a), Learning for Life: Education and Training Beyond the Age of Fifteen, Wellington: Government Printer.

Ministry of Education. (1989b), Learning for Life Two: Policy Decisions, Wellington: Government Printer.

Ministry of Education. (2002), Investing in Excellence: The Report of the Performance-Based Research Fund Working Group, http://www.tec.govt.nz/Funding/Fundfinder/Performance-Based-Research-Fund-PB (accessed 11 February 2010).

Ministry of Education. (2003), Tertiary Education Strategy 2002-2007, http://www.minedu.govt.nz/ /media/MinEdu/Files/EducationSectors/TertiaryEducati on/ (accessed 15 September 2008).

Ministry of Education. (2006a), Tertiary Education Strategy 2007-12: Incorporating Statement of Tertiary Education Priorities 2008-10, http://www.minedu.govt.nz/ /media/MinEdu/Files/EducationSectors/TertiaryEducati on/TertiaryEducationStrategy.pdf (accessed 15 September 2008).

Ministry of Education. (2006b), OECD Thematic Review of Tertiary Education: New Zealand Country Background Report, Wellington.

Ministry of Education. (2010), Research: Statistics Relating to Research and Knowledge Creation Including the Funding of Research, Research Outputs and Performance, http://www.educationcounts.govt.nz/statistics/tertiary_education/research (accessed 25 November 2010).

MoRST. (2006), Science for New Zealand: An Overview of the RS\&T System: Ministry of Research Science \& Technology, MoRST.

Mowery, D. C., Nelson, R., Sampat, B. and Ziedonis, A. (2001), "The Growth of Patenting and Licensing by U.S Universities: An Assessment of the Effects of the Bayh-Dole Act of 1980”, Research Policy, Vol. 30, pp. 99-119. 
New Zealand Government. (2002), Growing an Innovative New Zealand, http://www.executive.govt.nz/minister/clark/innovate/innovative.pdf (accessed 10 September 2009).

New Zealand Vice Chancellors Committee. (2008), University Research Commercialisation: Paying Dividends for New Zealand, http://www.universitiesnz.ac.nz/files/u2/NZVCC_Uni_ResearchFIN_1C59D.pdf (accessed 10 September 2009).

Nordfors, D., Sandred, J. and Wessner, C. (Eds.). (2003), Commercialization of Academic Research Results, VINNOVA, Verket for Innovations system/Swedish Agency for Innovation Systems.

OECD. (2003), Changing Patterns of Governance in Higher Education, Paris: OECD Publishing.

OECD. (2005), OECD Economic Surveys: New Zealand, Paris: OECD.

OECD. (2007), OECD Reviews of Innovation Policy: New Zealand, Paris: OECD.

OECD. (2008), Tertiary Education for the Knowledge Society - OECD Thematic Review of Tertiary Education, Paris: OECD.

OECD. (2009), “OECD Economic Surveys: New Zealand 2009”, OECD Economic Surveys, Vol. 2009, No.4, pp. 1-151.

Olssen, M. (2002), “The Restructuring of Tertiary Education in New Zealand: Governmentality, Neo-liberalism, Democracy”, McGill Journal of Education, Vol. 37(1), pp. 57-87.

Olssen, M. and Peters, M. A. (2005), "Neoliberalism, Higher Education and the Knowledge Economy: From the Free Market to Knowledge Capitalism”, Journal of Education Policy, Vol. 20, No. 3, pp. 313-345.

Peters, M. (1999), “Neoliberalism”, in Encylclopedia of Philosophy of Education, www.vusst.hr/ENCYCLOPAEDIA/neoliberalism.htm (accessed 1 May 2007).

Peters, M. A. (2006), "The Rise of Global Science and the Emerging Political Economy of International Research Collaborations”, European Journal of Education, Vol. 41(2), pp. 225-244.

Potter, B. N. (2005), “Accounting as a Social and Institutional Practice: Perspectives to Enrich our Understanding of Accounting Change”, Abacus, Vol. 41, No.3, pp. 265289.

Power, M. (1994), “The Audit Society”, in Hopwood, A. and Miller, P. (Eds.), Accounting as a Social and Institutional Practice, Cambridge University Press, pp. 299-316.

Rasmussen, E. (2008), “Government Instruments to Support the Commercialization of University Research: Lessons from Canada”, Technovation, Vol. 28(8), pp. 506-517.

Rasmussen, E., Moen, O. and Gulbrandsen, M. (2006), "Initiatives to Promote Commercialization of University Knowledge”, Technovation, Vol. 26(4), pp. 518533.

Rosenberg, N. and Nelson, R. (1994), “American Universities and Technical Advance in Industry, Research Policy, Vol. 23(3), pp. 323-348.

Servage, L. (2009), “The Scholarship of Teaching and Learning and the Neo-Liberalization of Higher Education: Constructing the Entrepreneurial Learner”, Canadian Journal of Higher Education, Vol. 39, No. 2, pp. 25-44.

Slaughter, S. and Leslie, L. L. (1997), Academic Capitalism. Politics, Policies, and the Entrepreneurial University, The John Hopkins University Press, Baltimore.

Statistics New Zealand. (2009), Crown Research Institute Statistics: Year ended 30 June 2009), http://www.stats.govt.nz/browse_for_stats/government_finance/crown_research_instit 
utes/CrownResearchInstituteStatistics_HOTPye30Jun09.aspx (accessed 20 May 2010).

TEAC. (2000), Shaping a Shared Vision: Initial Report of the Tertiary Education Advisory Commission, July 2000, Wellington.

TEAC. (2001a), Shaping the Strategy: Third Report of the Tertiary Education Advisory Commission, Wellington: Tertiary Education Advisory Commission.

TEAC. (2001b), Shaping the System: Second Report of the Tertiary Education Advisory Commission, Wellington: Tertiary Education Advisory Commission.

The University of Auckland. (2009), Annual Report 2009, http://www.auckland.ac.nz/uoa/archived-publications\#s2c1 (accessed 25 May 2010).

Treasury. (1987), Government Management: A Report to the Incoming Government, Wellington.

Vincent-Lancrin, S. (2006), "What is Changing in Academic Research? Trends and Futures Scenarios”, European Journal of Education, Vol. 41(2), pp. 169-202.

Winsley, P. (2003), "How we can Improve the Performance of New Zealand's Science System”, New Zealand Science Review, Vol. 60(2-3), pp. 75-80. 